\title{
URGENSI PEMBELAJARAN SEJARAH BERBASIS POTENSI LOKAL BAHARI UNTUK MENUMBUHKAN MINAT WIRAUSAHA DI PESISIR SELATAN KABUPATEN MALANG
}

\author{
Lutfiah Ayundasari \\ Jurusan Sejarah, Universitas Negeri Malang
}

\begin{abstract}
Abstrak: Potensi bahari menjadi salah satu aset dalam mengembangkan kesejahteraan masyarakat pesisir. Salah satu cara yang dapat dilakukan adalah dengan mengembangkan pembelajaran yang berbasis pada potensi daerahnya. Pembelajaran tersebut diharapkan mampu menumbuhkan minat wirausaha. Semua mata pelajaran di sekolah berpeluang mengambil peran ini, termasuk mata pelajaran sejarah. Kompetensi dasar yang dapat dikelola untuk menumbuhkan minat wirausaha adalah kompetensi dasar 3.1-3.7 karena masih bersifat umum. Pada kompetensi ini dimungkinkan untuk mengintegrasikan materi potensi lokal bahari sebagai bahan kajian. Integrasi materi ini diharapkan dapat menumbuhkan kepekaan peserta didik terhadap lingkungan sekitar berdasarkan fakta-fakta sejarah.
\end{abstract}

Kata-kata kunci: pembelajaran sejarah, potensi lokal bahari, minat wirausaha

\begin{abstract}
: marine potential becomes an asset in developing marine society's welfare. A way that can be done is to design a learning based on their areas potential. Learning is expected to foster entrepreneurial interest. All the lessons at school have the opportunity to take on this role, including history. Basic competence that can be managed to foster entrepreneurial interest is basic competence from 3.1 to 3.7 because these competences are still in general. In this competence, it is possible to integrate local marine potential material as a study. The integration of this material is expected to foster children's sensitivity to the environment based on the facts of history.
\end{abstract}

Keywords: history learning, maritime potential, entreprenurial intention

Kabupaten Malang merupakan kabupaten terluas kedua di Jawa Timur dengan beragam karakteristik dan potensi yang dimiliki. Secara umum kabupaten Malang dikenal terbagi menjadi dua yaitu Malang Utara dan Malang Selatan. Kedua wilayah ini memiliki perbedaan yang cukup jauh dari segi geografis, ekonomi, maupun demografi. Malang bagian utara merupakan daerah industri cukup maju, perusahaan besar yang beroperasi di wilayah ini mampu menyerap banyak tenaga kerja. Selain itu, akses yang lebih mudah menjadikan Malang Utara sebagai pusat pendidikan dan hiburan, kedua hal ini juga merupakan motor penggerak ekonomi bagi masyarakat selain industri. Kondisi ini berbeda jauh dengan Malang Selatan, wilayah ini cenderung lebih sepi sehingga tidak banyak perusahaan besar yang beroperasi, pun juga tidak terdapat pusat pendidikan dan hiburan yang mampu menciptakan lapangan pekerjaan. Hal ini dikarenakan jaraknya jauh dan kontur tanah yang bergunung-gunung.

Perbedaan ini sebetulnya mulai diatasi oleh pemerintah antara lain dengan cara memindahkan pusat pemerintahan ke arah selatan yaitu Kepanjen sejak tahun 2008 dan membangun jalan yang dikenal JLS (Jalur Lintas Selatan). Kedua usaha ini merupakan langkah penting untuk membangun kedekatan dengan wilayah selatan, namun rupanya masih belum memberikan hasil yang memuaskan karena masyarakat di Malang Selatan cenderung memilih bekerja di luar daerah bahkan di luar negeri. Dalam laporan 
tahunan 2012 tercatat 2.564 orang dari total 3.572 orang TKI di Kabupaten Malang berasal dari Malang Selatan (KMDA, 2013). Banyaknya jumlah TKI memang memberikan keuntungan secara finansial tetapi dampak sosial yang ditimbulkan juga tidak bisa dianggap ringan, contohnya kenakalan remaja, kriminalitas dan perceraian. Hal ini sebenarnya bisa diatasi jika masyarakat wilayah Malang Selatan mampu menciptakan lapangan kerja sendiri dengan berwirausaha, mengingat sebenarnya wilayah ini memiliki potensi alam yang dapat diandalkan, salah satunya adalah potensi bahari. Hal inilah yang menjadi dasar pentingnya merancang pembelajaran di sekolah yang mampu menumbuhkan minat untuk berwirausaha dengan memaksimalkan potensi lingkungan sekitar.

\section{KONDISI GEOGRAFIS, SOSIAL, DAN EKONOMI MALANG SE- LATAN}

Kabupaten Malang adalah sebuah kawasan yang terletak pada bagian tengah selatan wilayah Propinsi Jawa Timur. Berbatasan dengan enam kabupaten (Pasuruan, Probolinggo, Lumajang, Blitar, Kediri, Mojokerto) dan Samudera Indonesia. Dengan luas wilayah sekitar 3.238,26 Km2 (sumber; Balai Pengelolaan Daerah Aliran Sungai Brantas), Kabupaten Malang terletak pada urutan luas terbesar kedua setelah Kabupaten Banyuwangi dari 38 kabupaten/kota di wilayah Propinsi Jawa Timur. Secara umum Kabupaten Malang memiliki potensi hutan yang cukup besar karena dikelilingi oleh 10 gunung (KMDA, 2013). Hutan-hutan ini menjadi sumber bagi 18 sungai besar yang mengalir sepanjang tahun. Salah satu sungai yang cukup penting adalah Sungai Brantas yang bersumber di Kota Batu dan berhulu di Malang Selatan. Hulu Sungai Brantas bagian atas terdapat di Malang Selatan merupakan wilayah yang cukup luas dengan berbagai potensi yang harus dikembangkan demi kesejahteraan masyarakat.

Kondisi topografi seperti tersebut diatas menjadikan Kabupaten Malang memiliki beragam potensi, termasuk di wilayah Malang Selatan. Diwilayah ini terdapat pertemuan antara pegunungan dan pesisir. Di daerah pegunungan Malang Selatan ada banyak komoditas yang mampu dibudidayakan antara lain; (a) tanaman perkebunan seperti kopi, cengkih, lada dan tebu; (b) tanaman pertanian seperti padi (dibeberapa wilayah), singkong, pisang, manggis, salak dll. Dalam konteks wilayah pesisir komoditas yang potensial dikembangkan adalah perikanan beserta produk turunannya dan potensi bahari lain seperti pariwisata. Selain itu juga terdapat potensi tambang yang cukup besar yaitu pasir dan batu di kecamatan Ampelgading, kapur dan batu putih bahan keramik di kecamatan Sumbermanjing.

Keberagaman topografi dan potensi alam berimbas pada kondisi sosial ekonomi masyarakat Malang Selatan. Jika dicermati, masyarakat Malang Selatan terdiri dari masyarakat agraris, pesisir, dan industri. Keberagaman potensi ternyata tidak berbanding lurus dengan kesejahteraan masyarakat Malang Selatan, hal ini kemungkinan dikarenakan kurangnya pengelolaan dan akses ke pusat keramaian yang jauh. Dalam catatan pemerintah Kabupaten Malang edisi 2012 terekam bahwa 2.564 dari 3.572 jumlah TKI di Kabupaten Malang berasal dari Malang Selatan. Hal ini menjadi bukti bahwa banyak masyarakat Malang Selatan yang memilih keluar daerah atau bahkan luar negeri daripada mengusahakan kehidupan didaerah asalnya. Fenomena TKI telah merubah wajah pedesaan di Malang Selatan, perubahan yang terlihat jelas antara lain bangunan fisik rumah-rumah TKI, tingkat kesejahteraan, gaya hidup, masalah-masalah sosial sebagai side effect 
yang tidak diharapkan misal, tingginya angka perceraian dan kenakalan remaja.

\section{POTENSI BAHARI DAN MINAT WIRAUSAHA}

Indonesia merupakan negara maritim yang memiliki perairan seluas 2.8 juta $\mathrm{km}^{2}$ dengan laut teritorial seluas 0.3 juta $\mathrm{km}^{2}$, luas ZEE (Exlusive Economic Zone) sekitar 3,0 juta $\mathrm{km}^{2}$, dan panjang garis pantai lebih dari $81.000 \mathrm{~km}$. Potensi wilayah pesisir dan laut Indonesia dipandang dari segi pembangunan terbagi dalam beberapa klasifikasi sumberdaya yaitu: (a) sumber daya yang dapat diperbaharui seperti; perikanan (tangkap, budidaya, dan pascapanen), hutan mangrove, terumbu karang, industri bioteknologi kelautan dan pulau-pulau kecil. (b) sumber daya yang tidak dapat diperbaharui seperti; minyak bumi dan gas, bahan tambang dan mineral lainnya serta harta karun. (c) energi kelautan seperti; pasang-surut, gelombang, angin, otec (ocean thermal energy conversion), (d) jasajasa lingkungan seperti; pariwisata, perhubungan dan ke pelabuhanan serta penetralisir limbah (Kusumastanto, 2003). Hal ini merupakan potensi kekayaan alam yang mampu mendatangkan kesejahteraan jika pengelolaannya dilakukan secara sinergis melibatkan berbagai pihak.

Selama ini pemerintah telah melakukan upaya berkesinambungan dalam rangka peningkatan pengelolaan sumber daya kelautan. Pembagian hak kelola juga sudah diatur secara jelas dalam Undang-Undang No. 22 tahun 1999 tentang pemerintahan daerah dan - UU No.25 tahun 1999 tentang perimbangan keuangan pusat dan daerah. Dalam UU No.22 tahun 1999 terdapat aturan mengenai kewenangan daerah provinsi dalam pengelolaan wilayah lain dalam batasan 12 mil yang diukur dari garis pantai kearah laut lepas dan atau ke arah perairan kepulauan dan pemerintah kota / kabupaten berhak mengelola sepertiganya atau 4 mil laut seperti tercantum dalam pasal 3 dan pasal 10 ayat 2 dan 3. Sedangkan, UU No.25 Tahun 1999 mengandung aturan tentang pembagian alokasi pendapatan antara pemerintah pusat dan daerah yang berasal dari pemanfaatan sumber daya alam termasuk sumber daya pesisir dan laut.

Usaha-usaha tersebut merupakan langkah dalam tataran kebijakan yang dilakukan oleh aparatur negara. Merupakan hal yang cukup disayangkan karena baik secara eksplisit maupun implisit, pemerintah daerah ditingkat lokal (kabupaten/kota) belum menggunakan kesempatan ini untuk melibatkan lembaga pendidikan dalam rangka menumbuhkan minat terhadap pengeloaan potensi bahari. Dalam kasus yang dimaksud adalah di pesisir selatan Kabupaten Malang. Hal didasarkan pada data dan hasil wawancara yang menunjukkan bahwa pemuda-pemuda pesisir selatan kabupaten Malang lebih memilih untuk bekerja di luar daerah atau bahkan di luar negeri dalam rangka memenuhi kebutuhan ekonominya.

Salah satu daerah pesisir di Kabupaten Malang adalah Sumbermanjing, sebuah kecamatan yang terletak diujung selatan. Secara geografis wilayah ini terdiri dari pegunungan dan daerah pantai dengan potensi alam cukup besar antara lain tambang batu putih sebagai bahan dasar keramik, tanaman cengkih dan tebu, serta potensi bahari. Berbagai sumber daya ini ternyata tidak serta merta menjadikan penduduk Sumbermanjing menikmati kesejahteraan. Di kecamatan ini setidaknya terdapat sekitar 15 sampai 17 orang yang mengajukan ijin berangkat ke luar negeri setiap bulannya (Data Kesos Kecamatan Sumbermanjing tahun 2017). Rata-rata mereka yang berangkat keluar negeri adalah lulusan SD-SMP dengan alasan merasa sulit mendapatkan pekerjaan di lingkungan mereka tinggal. Selain itu juga karena hu- 
tang yang tidak mampu mereka bayar (wawancara dengan Kasi Kesos Kec. Sumbermanjing, 7 April 2017). Kondisi ini menggambarkan kesulitan hidup yang tidak mudah diatasi sehingga memaksa mereka keluar dari tempat asalnya.

Kecamatan Sumbermanjing memiliki wilayah yang cukup luas, pusat keramaian hanya berada disekitar kota kecamatan. Di sini terdapat pasar, pusat pemerintahan, dan pendidikan setingkat SMA/SMK. Dari pusat kecamatan ke daerah pantai membutuhkan waktu tempuh sekitar satu jam lebih dengan jalanan yang sepi. Kemungkinan hal inilah yang menyebabkan kenapa tingkat pendidikan masyarakat Sumbermanjing tertama dibagian pesisir rendah, rata-rata mereka hanya mengenyam pendidikan setingkat SD-SMP, setelah itu anak-anak akan lebih memilih bekerja sebagai pandega atau mendaftar sebagai TKI. Hal ini bisa dimaklumi karena jika mereka akan melanjutkan sekolah maka harus ke kota kecamatan dengan jarak yang cukup jauh dan jalan yang sepi, ditambah dengan angkutan yang tidak bisa dipastikan jamnya. Bahkan jika ingin mendapatkan sekolah yang bagus maka mereka harus rela pergi lebih jauh ke Turen atau Kepanjen dengan konsekuensi menjadi anak kos yang tentu biayanya akan berlipat ganda. Kesempatan baik ini hanya dimiliki oleh orangorang kaya saja.

Kembali kepada permasalahan awal dimana sebenarnya Kecamatan Sumbermanjing yang terletak di pesisir selatan Kabupaten Malang memiliki potensi beragam, terutama potensi bahari berupa hasil laut dan pariwisata. Sedangkan kondisi yang ada saat ini belum mencerminkan pemanfaatan potensi bahari sebagai sarana menuju kesejahteraan masyarakat. Salah satu akses percepatan menuju kesejahteraan antara lain dengan kewirausahaan. Timmons \& Spinelli (2004: 31) mengidentifikasi bahwa kewirausahaan merupakan suatu cara berpikir, menelaah, dan bertindak yang didasarkan pada peluang bisnis, pendekatan holistik, dan kepemimpinan yang seimbang. Sedangkan pelaku kewirausahaan yaitu wirausaha merupakan seorang inovator yang mampu mengubah kesempatan menjadi sebuah ide yang bisa dijual, dapat memberikan nilai tambah melalui upaya, waktu, biaya serta kecakapan dengan tujuan mendapatkan keuntungan (Machfoedz, 2004). Sehingga dapat disimpulkan bahwa dalam rangka meningkatkan pemanfaatan potensi bahari pesisir selatan Kabupaten Malang dilakukan dengan menumbuhkan individu-individu yang mampu melihat peluang dan mencetuskan ide melalui telaah dan refleksi terhadap lingkungan sekitar, sehingga mereka dapat menganalisis potensipotensi apa yang perlu dikembangkan dan diberi nilai tambah demi tercapainya kesejahteraan.

Menjadi seorang wirausaha tidak berarti harus berpendidikan tinggi, yang lebih penting dari hal tersebut adalah minat wirausaha dan kemauan kuat. Sarwoko (2011) menyatakan bahwa minat berwirausaha (Entreprenurial Intention), merupakan tendensi keinginan individu melakukan tindakan berwirausaha dengan menciptakan produk baru melalui peluang bisnis dan pengambilan risiko. Dalam rangka menciptakan hal tersebut dibutuhkan kondisi-kondisi yang mampu merangsang individu melakukan refleksi atas lingkungan, melihat potensi, menciptakan kreasi dan menyusun strategi menghadapi tantangan sosial ekonomi. Hal ini senada dengan pernyataan Alma (2010:12) bahwa faktor pendorong dalam memasuki karir sebagai wirausaha adalah adanya kepribadian wirausaha dan lingkungan.

Lingkungan merupakan faktor yang tidak bisa dikesampingkan termasuk dalam proses menumbuhkan minat wirausaha, baik lingkungan keluarga, masyarakat, 
maupun sekolah. Dewasa ini usaha untuk menumbuhkan minat wirausaha bagi peserta didik secara formal dalam bentuk kurikulum diberikan di jenjang pendidikan menengah atas (SMK) dan tinggi. Hal ini dilakukan dengan harapan dapat memunculkan individu yang memiliki kemandirian ekonomi, mengingat semakin banyak pengangguran terdidik. Lembaga pendidikan merupakan agen perubahan yang penting bagi generasi selanjutnya, karena dengan kebijakan fullday school bisa dipastikan bahwa sebagian besar kehidupan anak-anak digunakan di sekolah. Oleh karena itu sebaiknya penciptaan kondisi demi tumbuhnya minat wirausaha dilakukan disemua jenjang pendidikan.

\section{PEMBELAJARAN SEJARAH LOKAL MASYARAKAT PESISIR}

Kelokalan atau sesuatu yang bersifat lokal saat ini menjadi tren sebagai perwujudan identitas di tengah arus globalisasi yang tak terbendung diberbagai bidang termasuk ekonomi. Pasar bebas merupakan manifestasi globalisasi ekonomi yang dapat dipahami sebagai peluang sekaligus tantangan, namun jika belum siap hal ini akan berdampak pada semakin tertinggalnya rakyat Indonesia dikancah dunia. Oleh karena itu pengarus-utamaan glokalisasi menjadi salah satu jalan bagi usaha memposisikan diri secara tangguh dalam persaingan diera globalisasi. Glokalisasi merupakan istilah yang dipopulerkan oleh Roland Robertson, merupakan adaptasi dari bahasa Jepang yaitu dochakuka yang berarti adaptasi teknik bertani yang dipadukan dengan kegiatan setempat. Dalam dunia usaha glokalisasi dikenal sebagai sebuah istilah untuk menyebut strategi pemasaran yang digunakan oleh Jepang untuk memasarkan produknya agar sesuai dengan selera pasar (Khondker, 2004:4).

Seiring berjalannya waktu ada perubahan makna tentang glokalisasi, secara umum diartikan sebagai berikut; 1 . keragaman adalah inti dari kehidupan sosial; 2. globalisasi tidak menghapus semua perbedaan; 3. otonomi sejarah dan budaya memberikan keunikan pengalaman kelompok sebagai budaya, masyarakat atau negara; 4 . glokalisasi adalah gagasan yang menghilangkan rasa takut atas globalisasi, gelombang pasang yang menghapus semua perbedaan (Khondker, 2004:5). Dalam konteks ini glokalisasi diharapkan mampu memberikan keunikan bagi kelompok tertentu yang berwujud tindakan kemandirian agar tidak terlalu risau dengan globalisasi sekaligus merayakan keberagaman Indonesia sebagai inti kehidupan sosial dan persatuan. Hal ini juga perlu diterapkan dibidang pendidikan sebagai usaha mempersiapkan generasi muda yang mampu beradaptasi dengan kemajuan dunia.

Penerapan glokalisasi di bidang pendidikan, khususnya pembelajaran sejarah dapat dilakukan dengan merancang integrasi sejarah lokal dalam proses pembelajaran di sekolah. Ide tentang penulisan sejarah lokal sudah berlangsung cukup lama, tepatnya banyak bermunculan dalam acara Seminar Sejarah Lokal di Medan tahun 1984. Menurut Kuntowijoyo adanya ide-ide tentang sejarah lokal menunjukkan adanya semangat interdisipliner dikalangan sejarawan, dan ini merupakan kemajuan yang berarti (Kuntowijoyo, 2003:145). Kehadiran sejarah lokal telah membantu sejarawan untuk melangkah keluar dari zona umum dimana sejarah hanya berisi tentang orang dan peristiwa besar. Kesempatan ini membuka cakrawala baru bahwa sejarah adalah milik semua tidak hanya penguasa. Euforia kemunculan tema-tema baru dalam penulisan sejarah terus berlanjut dan menyebar sampai ditingkat pembelajaran disekolah meskipun membutuhkan waktu yang tidak sebentar. Setidaknya akses resmi integrasi materi-materi sejarah lokal dalam pembelajaran sejarah baru dapat dilakukan setelah 
pemberlakuan KTSP 2006. Hal ini cukup mampu mendekatkan materi pelajaran sejarah dengan lingkungan sekitar peserta didik. Mengingat seringkali karena amanat kurikulum pembelajaran sejarah berisi tentang tema-tema besar yang jauh dari lingkungan sekitar.

Berdasarkan deskripsi kurikulum yang ada selama ini pembelajaran sejarah dikenal sebagai sarana untuk menanamkan nilai-nilai afektif seperti empati, simpati, toleransi, kepahlawanan, keteladanan, kepeloporan, patriotisme, dan nasionalisme. Tugas lain yang diemban oleh mata pelajaran sejarah yaitu membangun kohesi dan identitas nasional, serta pewarisan nilai, etika, dan budaya kepada peserta didik (Agung \& Sri Wahyuni 2013, Aman 2011, Depdiknas 2006). Penekanan terhadap tercapainya ranah kognitif dan afektif menjadi fokus para akademisi dalam melakukan penelitian termasuk bagi mahasiswa. Sebagian besar penelitian yang mengkaji tentang pembelajaran sejarah berpusat disekitar penggunaan model/metode/strategi, penyusunan media dan evaluasi, serta tentang persepsi terhadap kebijakan maupun proses. Aspek yang terlupa dalam analisa mengenai pembelajaran sejarah adalah kebermanfaatan praktis dalam kehidupan sehari-hari sejalan dengan kondisi lingkungan sekitar sebagai upaya menghadap globalisasi.

Dalam rangka memberikan kebermanfaatan tersebut perlu disosialisasikan lagi bahwa peran pembelajaran sejarah tidak terbatas pada masalah-masalah ideologis afektif tetapi juga masalah-masalah praktis. Berdasarkan kurikulum dan analisa para ahli bahwa matapelajaran sejarah memiliki manfaat antara lain; mengatasi krisis multidimensi yang dihadapi dalam kehidupan sehari-hari; menanamkan dan mengembangkan sikap bertanggung jawab dalam memelihara keseimbangan dan kelestarian lingkungan hidup; mengembangkan imajinasi dan sikap kreatif, inovatif, serta partisipatif; membantu mencarikan jalan keluar bagi berbagai masalah sosial dan perorangan; mengembangkan ketrampilan yang berguna; mendorong siswa berpikir kritis-analitis dalam memanfaatkan pengetahuan tentang masa lampau untuk memahami kehidupan masa kini dan yang akan datang; mengembangkan kemampuan intelektual dan keterampilan untuk memahami proses perubahan dan keberlanjutan masyarakat (Agung \& Sri Wahyuni 2013, Aman 2011, Diknas 2006, Kochar 2008).

Harus diakui memang tidak semua kompetensi dasar dalam mata pelajaran sejarah dapat disisipkan materi-materi yang dapat memberikan kebermanfaatan secara praktis. Namun setidaknya, terdapat beberapa kompetensi dasar yang dapat disajikan dengan menggunakan potensi dan kekhasan lokal daerah sebagai bahan kajian yaitu kompetensi dasar 3.1-3.7. Kompetensi dasar ini berisi materi-materi umum tentang sejarah dan ilmu sejarah. Misalnya kompetensi dasar 3.2 tentang kehidupan manusia dalam perubahan dan keberlanjutan diajarkan di masyarakat pesisir. Dalam pembelajaran berdasarkan kompetensi dasar ini siswa diminta untuk melakukan analisis melalui pengamatan dan wawancara sederhana kepada keluarga mereka tentang kehidupan masyarakat secara ekonomi, sosial, budaya. Perubahan apa saja yang telah terjadi, bagaimana dampaknya, perbaikan apa yang harus dilakukan agar masyarakat pesisir tetap lestari dan semakin sejahtera. Hal ini bisa didukung oleh fakta dan pengetahuan yang disajikan guru bahwa Indonesia merupakan negara maritim yang pernah berjaya dimasa emporium.

Mengulas kembali tentang kejayaan masyarakat pesisir dalam pembelajaran sejarah secara akademis diharapkan mampu mendekatkan materi dengan kondisi sekitar 
sehingga pembelajaran akan bermakna. Selain itu juga mampu menghadirkan semangat baru bagi peserta didik yang berada didaerah pesisir, mengingat dewasa ini masyarakat pesisir yang mayoritas bermata pencaharian sebagai nelayan kebanyakan berada dibawah garis kemiskinan kecuali para juragan darat dan juragan laut. Hal ini pula yang terjadi di Sumbermanjing, salah satu kecamatan yang terletak di pesisir selatan pulau Jawa. Kondisi ekonomi seringkali memaksa anak-anak bersekolah sampai SMP selebihnya mereka memilih bekerja bahkan kemudian banyak yang menjadi TKI. Mengajak siswa untuk mengamati, melakukan refleksi, berimajinasi tentang apa yang bisa dilakukan dapat menjadi salah satu langkah agar pembelajaran sejarah tidak hanya berkisar pada aspek ideologis afektif tetapi juga memiliki kemanfaatan praktis, misalnya menumbuhkan minat wirausaha.

Minat wirausaha bagi peserta didik dilingkungan masyarakat pesisir sangat dibutuhkan agar mereka tidak terikat dengan kondisi masyarakat nelayan yang seringkali kurang beruntung. Secara umum para penangkap ikan atau yang sering kita sebut sebagai nelayan mendapatkan uang dengan dua usaha penangkapan yaitu penangkapan ikan lepas pantai dan penangkapan ikan dekat pantai (Masyhuri, 1996:56). Dari keduanya yang menghasilkan keuntungan besar adalah penangkapan ikan lepas pantai yang membutuhkan modal cukup besar untuk perahu, peralatan, pengawetan ikan, bahan bakar, dan logistik. Harga perahu sederhana yang digunakan untuk penangkapan ikan lepas pantai berkisar antara 250-300 juta dengan waktu berlayar satu minggu (Wawancara dengan Suhartono, 7 April 2017). Besarnya modal yang dibutuhkan membuat tidak semua nelayan dapat melakukan hal tersebut, itulah kenapa kebanyakan mereka yang tidak punya modal memilih melaut dekat pantai atau menjadi pandega dari perahu besar. Dalam kasus di kecamatan Sumbermanjing, nelayan atau anak-anak mereka yang tidak memiliki modal besar memilih bekerja sebagai pandega atau bekerja diluar daerah bahkan diluar negeri. Hal ini juga berlaku bagi nelayan yang terlilit hutang, merupakan hal umum bagi nelayan yang tidak memiliki modal untuk berhutang terlebih dahulu dan mereka akan membayarnya sepulang menangkap ikan. Alasan inilah yang menjadi titik tolak pentingnya wirausaha bagi masyakarat pesisir.

\section{PEMBELAJARAN SEJARAH BER- BASIS POTENSI LOKAL BAHARI UNTUK MENUMBUHKAN MINAT WIRAUSAHA}

Sejarah merupakan bidang yang bersifat sangat umum, tidak ada hal yang tidak bisa dikisahkan. Kelebihan ini memberikan keuntungan baik bagi sejarawan maupun guru. Bagi guru sifat ini menguntungkan karena ada beragam materi yang dapat diintegrasikan sesuai dengan tujuan yang akan dicapai. Berdasarkan kurikulum, matapelajaran sejarah memiliki arti strategis dalam pembentukan watak dan peradaban bangsa yang bermartabat serta dalam pembentukan manusia Indonesia yang memiliki rasa kebangsaan dan cinta tanah air (Depdiknas, 2006). Namun sebenarnya pembelajaran sejarah dapat dikemas agar dapat memberikan arti lebih bagi peserta didik, antara lain sebagai salah satu sarana menumbuhkan minat wirausaha. Terdengar sangat jauh memang, karena menghubungkan matapelajaran sejarah dengan tujuan yang biasanya digarap oleh matapelajaran ekonomi. Tetapi bukan hal mustahil karena keberadaan sejarah lokal telah membuka peluang bagi kajian maupun pembelajaran yang bersifat interdisipliner.

Lingkungan pesisir dan lokalitas bahari merupakan salah satu kajian sejarah lokal yang dapat diintegrasikan dalam 
matapelajaran sejarah di sekolah-sekolah yang berada dilingkungan pantai. Hal ini dilakukan agar; pertama, mendekatkan materi pelajaran dengan lingkungan peserta didik agar pembelajaran sejarah bermakna; kedua, peserta didik tidak tercerabut dari akar budayanya; ketiga, menciptakan kebanggan dan keterikatan yang berdampak pada munculnya rasa tanggungjawab untuk ikut menjaga dan memajukan lingkungan; keempat, menumbuhkan minat wirausaha dari hasil pengamatan dan refleksi terhadap lingkungan sekitar; kelima sebagai salah satu langkah glokalisasi agar kedepan mereka mampu memposisikan diri sebagai masyarakat pesisir yang berdaya saing dengan memanfaatkan potensi lokal.

Kompetensi dasar matapelajaran sejarah yang dapat disisipi materi-materi potensi lokal bahari adalah 3.1-3.7. Kompetensi dasar ini tercantum di kurikulum sekolah menengah atas kelas $\mathrm{X}$ yang berisi pengetahuan umum tentang sejarah dan ilmu sejarah. Mengingat di kecamatan Sumbermanjing pesisir tidak terdapat SMA, maka pembelajaran ini dapat dilakukan di pusat kecamatan Sumbermanjing. Hal ini tidak menjadi masalah karena anak-anak pesisir yang ingin melanjutkan ke jenjang SMA akan pergi ke pusat kecamatan. Dalam proses pembelajaran, peserta didik sebanyak mungkin dirangsang untuk mengeksplorasi kondisi lingkungan pesisir dimana mereka tinggal, mengidentifikasi kekurangankekurangan apa yang membuat daerah mereka tertinggal, poten si-potensi apa yang dapat diberdayakan sebagai solusi bagi permasalahn ekonomi mereka. Sebelum masuk dalam kegiatan tersebut, mereka diberi apersepsi berupa pengetahuan tentang kejayaan bahari Indonesia di masa emporium.

\section{SIMPULAN}

Fenomena keberangkatan masyarakat Malang Selatan keluar negeri atau luar daerah untuk bekerja mengindikasikan rendahnya tingkat kepercayaan masyarakat terhadap keberhasilan pengelolaan potensi lokal sebagai sumber matapencaharian mereka. Penyelesaian masalah ini merupakan tanggungjawab bersama termasuk lembaga pendidikan. Sebagai sebuah lembaga yang berperan menyiapkan generasi penerus bangsa, sekolah harus mulai berbenah diri dengan tidak hanya berorientasi pada ranah kognitif afektif tetapi juga praktis dengan cara menumbuhkan individu-individu yang mampu melihat peluang dan mencetuskan ide melalui telaah dan refleksi terhadap lingkungan sekitar, sehingga mereka dapat menganalisis potensi-potensi apa yang perlu dikembangkan dan diberi nilai tambah demi tercapainya kesejahteraan.

Dalam sejarah Indonesia kejayaan dibidang maritim merupakan bukti bahwa pada dasarnya masyarakat mampu mengelola potensi lokal bahari sebagai sumber kesejahteraan. Oleh karena itu, sebenarnya matapelajaran sejarah memiliki peluang besar dalam mengembalikan kepercayaan diri masyarakat pesisir untuk berwirausaha. Memang dibutuhkan waktu lebih untuk menganalisis kompetensi dasar yang sesuai dan merancang pembelajaran demi tercapainya tujuan tersebut. Namun, hal ini tetap harus dilakukan mengingat pada dasarnya matapelajaran sejarah juga mengemban misi penting untuk mengembangkan imajinasi dan sikap kreatif, inovatif, serta partisipatif dalam rangka membantu mencarikan jalan keluar bagi berbagai masalah sosial dan perorangan.

\section{DAFTAR RUJUKAN}

Agung, $\quad \begin{gathered}\text { L } \\ \text { Wahyuni.2013.Perencanaan }\end{gathered}$


Pembelajaran Sejarah.Yogyakarta: Ombak.

Alma, B. 2010. Kewirausahaan (edisi revisi). Bandung: CV Alfabeta.

Aman.2011. Model Evaluasi Pembelajaran Sejarah.Yogyakarta: Ombak.

Departemen Pendidikan dan Kebudayaan.(2006).Peraturan Mendiknas No 22 Tahun 2006.Jakarta: Depdiknas.

Khondker, H.H. Glocalization as globalization: Evolution of a Sociological Concept. Bangladesh $e$ Journal Sociology, 1(2), pp 19.

Kochar, S.K.2008. "Teaching Of History. Jakarta: Grasindo.

Kusumastanto, T. (2003). Pemberdayaan Sumberdaya Kelautan, Perikanan dan Perhubungan Laut dalam Abad XXI. Pusat Kajian Sumberdaya Pesisir dan Lautan, Institut Pertanian Bogor.

Machfoedz, M dan Mahmud Machfoedz. 2004. Kewirausahaan. Yogyakarta : Akademi Manajemen Perusahaan YKPN.

Masyhuri.1996. Menyisir Pantai Utara: Usaha dan Perekonomian $\mathrm{Ne}$ layan di Jawa dan Madura 1850-1940. Jakarta: Yayasan Pustaka Nusatama.

Sarwoko, E. 2011. Kajian Empiris Entrepreneur Intention. Jurnal Ekonomi dan Bisnis. 16(2): $\mathrm{h}: 126-135$.

Timmons, Jeffry A. \& Spinelli, S., Jr. (2008). New Venture Creation. Kewirausahaan untuk Abad 21. Yogyakarta: Andi.

Narasumber

1. Slamet, Kasi Kesejahteraan Sosial Kecamatan Sumbermanjing

2. Suhartono, Juragan darat dari Kampung Baru Sendang Biru 